\title{
Is the External Audit Report Useful for Bankruptcy Prediction? Evidence Using Artificial Intelligence
}

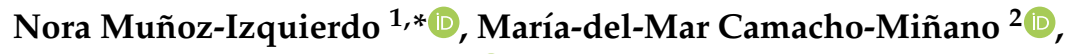 \\ María-Jesús Segovia-Vargas ${ }^{2}\left(\mathbb{D}\right.$ and David Pascual-Ezama ${ }^{2}$ \\ 1 CUNEF-Colegio Universitario de Estudios Financieros, Leonardo Prieto Castro, 2, Ciudad Universitaria, \\ 28040 Madrid, Spain \\ 2 Facultad de Ciencias Económicas y Empresariales, Complutense University of Madrid, Campus de \\ Somosaguas, Pozuelo de Alarcón, 28223 Madrid, Spain; marcamacho@ccee.ucm.es (M.-d.-M.C.-M.); \\ mjsegovia@ccee.ucm.es (M.-J.S.-V.); david.pascual@ccee.ucm.es (D.P.-E.) \\ * Correspondence: nmunoz@cunef.edu; Tel.: +34-650-96-19-08
}

Received: 6 November 2018; Accepted: 23 March 2019; Published: 8 April 2019

\begin{abstract}
Despite the number of studies on bankruptcy prediction using financial ratios, very little is known about how external audit information can contribute to anticipating financial distress. A handful of papers have shown that a combination of ratios and audit data is significant for predictive purposes, but only one recent paper provided a predictive accuracy of $80 \%$ solely by using the disclosures contained in audit reports. This study was complemented by simplifying the analysis of audit reports for prediction purposes and the same predictive accuracy was achieved. By applying three artificial intelligence techniques (PART algorithm, random forest, and support vector machine), the predictive ability of more easily extracted information from the report was examined and a practical implication suggested for each user. Simply by (1) finding the audit opinion, (2) identifying if a matter section exists, and (3) the number of comments disclosed, any user may predict a bankruptcy situation with the same accuracy as if they had scrutinized the whole report. In addition, an extended literature review is included, on previous studies on the interaction between bankruptcy prediction and the external audit information.
\end{abstract}

Keywords: bankruptcy prediction; audit report; artificial intelligence; PART algorithm

JEL Classification: G33; M40; M41; M42; C14

\section{Introduction}

During the last 70 years, the development of bankruptcy prediction models has been a challenging research topic worldwide (Sun et al. 2014; Cultrera and Brédart 2016; Altman 2018). Despite the number of studies in this field, recent literature indicates there is still a need to improve the accuracy of the prediction models (Balcaen and Ooghe 2006; Du Jardin 2015; Bauweraerts 2016) and there is a call to apply different sources of data and techniques, such as non-parametric techniques, to tackle this issue (Calderon and Cheh 2002; Zięba et al. 2016; Amani and Fadlalla 2017). This paper aimed to contribute to this line of research by examining the bankruptcy predictive ability of the external audit report using artificial intelligence methodologies.

The objective of this study was two-fold. First, it examined whether or not the audit report provided significant explanatory power when predicting bankruptcy by applying three artificial intelligence classifiers: the Projective Adaptive Resonance Theory (PART) algorithm, random forest, and support vector machine. Second, by testing the predictive ability of the audit report, a practical implication could be provided for each user, as it was easy to extract information from the report to 
make decisions related to a firm's viability. It was proposed that the three variables found without any difficulty in the audit report-the audit opinion, the type of paragraphs disclosed, and the number of comments included in those paragraphs-are significant variables to improve the detection of bankruptcy.

While considerable research has been devoted to bankruptcy prediction using financial ratios (Altman et al. 2017), very little is known about how external audit information can contribute to anticipating a firm's precarious financial condition. Considering that the auditing profession ensures the quality of financial statements with the issuance of an opinion in the audit report (Lennox 1999), it seems reasonable to expect that the information extracted from the report can represent a good indicator of a firm's insolvency.

Only a handful of papers have combined accounting ratios and some audit variables for predictive purposes (Altman and McGough 1974; Hopwood et al. 1989; Laitinen and Laitinen 2009; Altman et al. 2010; Piñeiro-Sánchez et al. 2013; Cenciarelli et al. 2018). Altman and McGough (1974) were pioneers in using audit information to predict bankruptcy. Hopwood et al. (1989) focused on some audit qualifications, finding that there was an association between bankruptcy and consistency, going concern, and other "subject to" qualifications. Altman et al. (2010) suggested that the audit opinion had high predictive power, and that firms with audit qualifications, such as severe qualifications or going concern, were more likely to fail, since the auditor was questioning its viability. Others, such as Piñeiro-Sánchez et al. (2013), examined the predictive ability of different auditor characteristics. According to their evidence, the auditor rotation, qualified reports, and non-compliance with deadlines (regarding approval and filing of financial statements) presented relevant differences between bankrupt and non-bankrupt firms. Similarly, Cenciarelli et al. (2018) posited that firms audited by industry-expert, large, and long-tenured auditors were less likely to fail. They also found that prediction models were more effective when the auditor attributed complementary financial characteristics.

A paper by Muñoz-Izquierdo et al. (2019) is the only one that has not combined audit data with accounting ratios to explain business failures. They anticipated the causes of business failure by solely applying external audit variables, namely, the narrative disclosures of the audit report. Narrative disclosures are the comments that auditors mention in the paragraphs regarding accounting and environmental issues that occur in the audited firms. They suggested that failure can be explained by specific internal causes, such as asset valuation and a firm's real and potential debts, as well as the external circumstances like the regulatory framework or changes in the market. However, obtaining this information from the audit report is not quick and easy. It takes time to interpret every comment, and users should have extended accounting or auditing knowledge to be able to understand the content of all disclosures. Therefore, the current paper contributes by simplifying the task of detecting business failure for the users of the audit report, so that stakeholders interested in the business's future viability will not need to scrutinize the complete report.

The current paper is a follow-up study to that of Muñoz-Izquierdo et al. (2019), and also uses information from the audit report in isolation (not combined with financial data) for bankruptcy estimation purposes. As previously stated, the aim of this paper was different because it attempted to anticipate bankruptcy, that is, to find an accurate percentage of prediction and not the particular causes of the bankruptcy situation. Furthermore, the aim was to do so by using the minimum number of variables extracted from the audit report, and those easiest to identify by any user. New variables were introduced that users could obtain without being experts on the valuation of assets and liabilities, policy changes, or the markets in which the firms operate.

The results of this study suggest that three easily extracted audit report variables could provide a reasonably accurate bankruptcy predictive power, similar to the one obtained in prior works that combined accounting with auditing variables. These variables are the audit opinion, the matter sections disclosed in the audit reports, and the number of comments included in the matter sections and qualification paragraphs. Thus, the findings indicate that there is a positive relationship between the propensity to file for bankruptcy and the issuance of qualified reports with a high number of comments 
disclosed by the auditors. There was even a positive relationship between the bankruptcy filing and unqualified reports with comments disclosed in the matter paragraphs. Since the audit report is a standardized and regulated document, these variables are easily detected by any user without the need to scrutinize the whole report or having any special accounting or auditing knowledge. This empirical evidence shows a practical implication for the users of the audit report-a simple identification of the opinion, the type of paragraphs disclosed, and the number of auditors' comments represents a substantive approach to detect and estimate bankruptcy. A contribution to the bankruptcy prediction literature was made by applying three different artificial intelligence methodologies, which have never applied before with auditing variables. Lastly, this study also provides an extensive review of the research into the interaction between bankruptcy and auditing research, thus contributing to both areas of knowledge.

\section{Literature Review and Research Question}

Auditors are required to express in the audit report if the likelihood of default is high during the one-year period following the issuance of the document (McKee 2003). Although the role of auditors is not expected to be a predictor of bankruptcy, stakeholders might be dissatisfied if a firm fails immediately after receiving an unqualified opinion. This issue has persisted for many years, and the auditing literature has considered audit quality from the viewpoint of the users of the financial statements. Indeed, during the last global financial crisis, companies sought financial support within a short period after receiving an unqualified opinion (Sikka 2009). Since then, researchers have paid more attention to the association between bankruptcy and the auditing profession, suggesting that the propensity to issue going concern opinions prior to bankruptcy increases after a crisis (Geiger et al. 2014). However, evidence about the auditors' ability to warn investors about upcoming failures is not unanimous, as other prior studies have suggested that investors perceive audit reports as informative (Dopuch et al. 1987; Piñeiro-Sánchez et al. 2013), emphasizing that audit opinions provide explanatory power for predicting bankruptcy (Kim et al. 2008; Altman et al. 2010).

A systematic literature review was conducted to present the state-of-the-art literature regarding the relationship between the external audit information and the prediction of bankruptcy, and to show the contribution of the current study.

\subsection{Systematic Literature Review: Scope of the Review}

All of the academic papers from the Institute for Scientific Information (ISI) Web of Knowledge database as of December 2018 were compiled according to two keywords: "audit" and "bankruptcy". The preliminary search identified many papers focused on the broad domains of bankruptcy. The process of reading the abstracts and introductions of the articles led to the further elimination of studies outside the scope of this research. After filtering the results, 86 articles on the integration between auditing and bankruptcy remained for this study. With the purpose of systematizing and organizing the literature, these papers were assembled and classified according to their main themes, by dividing them into four lines of research: the effects of auditing; audit quality and auditor independence; audit opinion prediction; and bankruptcy prediction using auditing. The contribution of the current study will fall into this fourth category, although all four lines are absolutely interconnected. A list of the reviewed articles appears in Table 1, explaining their samples, methodologies, and key findings. 
Table 1. Literature review of bankruptcy and auditing.

\begin{tabular}{|c|c|c|}
\hline Studies/Year & $\begin{array}{l}\text { Sample (Country/Type of } \\
\text { Firms/Years/Number) }\end{array}$ & Key Findings/Methodology \\
\hline \multicolumn{3}{|c|}{ Line of research: Effects of auditing } \\
\hline Lowe and Reckers (1994) & US/92 prospective jurors & $\begin{array}{l}\text { Outcome knowledge biases jurors' evaluations of the } \\
\text { auditor's judgement/Experiment }\end{array}$ \\
\hline $\begin{array}{l}\text { Menon and Williams } \\
\text { (1994) }\end{array}$ & $\begin{array}{l}\text { US/Public/1990/100 L\&H clients } \\
\text { and } 4523 \text { non-L\&H clients }\end{array}$ & $\begin{array}{l}\text { The disclosure of bankruptcy has an adverse effect on } \\
\text { market prices and the market does not react to an auditor's } \\
\text { replacement/Multivariate test (OLS) }\end{array}$ \\
\hline Chen and Church (1996) & US/Public/1980-1988/98 bankrupt & $\begin{array}{l}\text { Firms receiving GCOs experience less negative excess } \\
\text { returns in the period surrounding bankruptcy filings than } \\
\text { those receiving clean opinions/Multivariate test (logit) }\end{array}$ \\
\hline $\begin{array}{l}\text { Buchman and Collins } \\
\text { (1998) }\end{array}$ & $\begin{array}{l}\text { US/Public/1977/60 with qualified } \\
\text { opinions for litigation uncertainty } \\
\text { and } 331 \text { with unqualified }\end{array}$ & $\begin{array}{l}\text { Qualified opinions are useful for financial statement users in } \\
\text { predicting material litigation losses/Multivariate test (logit) }\end{array}$ \\
\hline Charitou et al. (2007) & $\begin{array}{l}\text { US/Public/1986-2004/859 bankrupt } \\
\text { and } 859 \text { non-bankrupt }\end{array}$ & $\begin{array}{l}\text { Managers of highly distressed firms shift earnings } \\
\text { downward before filing for bankruptcy/Multivariate test } \\
\text { (earnings management accrual models) }\end{array}$ \\
\hline Blay et al. (2011) & $\begin{array}{l}\text { US/Public/1989-2006/431 with } \\
\text { GCO and } 431 \text { without }\end{array}$ & $\begin{array}{l}\text { GCOs represent a risk communication to the equity market } \\
\text { and result in a shift of the market's perception of distressed } \\
\text { firms/Multivariate test (models based on Barth et al. 1998) }\end{array}$ \\
\hline $\begin{array}{l}\text { Van Caneghem and Van } \\
\text { Campenhout (2012) }\end{array}$ & Belgium/Private/2007/79,097 SMEs & $\begin{array}{l}\text { The amount and quality of financial statement information is } \\
\text { positively related to the SMEs' financial structures } \\
\text { (leverage)/Multivariate test (OLS) }\end{array}$ \\
\hline Stanisic et al. (2013) & $\begin{array}{l}\text { Serbia/2007-2011/163 audit reports } \\
\text { of } 33 \text { banks }\end{array}$ & $\begin{array}{l}\text { Special attention should be paid to banks with explanatory } \\
\text { paragraphs or qualifications on their auditors' } \\
\text { reports/Univariate analyses }\end{array}$ \\
\hline Amin et al. (2014) & $\begin{array}{l}\text { US/Public/2000-2010/114 firm-year } \\
\text { observations with GCOs and } 5343 \\
\text { without }\end{array}$ & $\begin{array}{l}\text { There is a positive relationship between the issuance of a } \\
\text { GCO and the firm's subsequent cost of equity } \\
\text { capital/Multivariate test (models based on Khurana and } \\
\text { Raman (2006) and Ogneva et al. (2007)) }\end{array}$ \\
\hline Eutsler et al. (2016) & US/Public/1995-2012/314 fraud & $\begin{array}{l}\text { Auditors are penalized for documenting their awareness of } \\
\text { fraud risk if subsequent financial statements are } \\
\text { fraudulent/Multivariate test (probit) }\end{array}$ \\
\hline Chen et al. (2016) & US/Public/1992-2009/5377 & $\begin{array}{l}\text { Loan contracts incorporate information contained in } \\
\text { qualifications/Multivariate test (OLS and probit) }\end{array}$ \\
\hline $\begin{array}{l}\text { Kausar and Lennox } \\
\text { (2017) }\end{array}$ & $\begin{array}{l}\text { UK/Public/1994-2008/120 } \\
\text { bankrupt }\end{array}$ & $\begin{array}{l}\text { Conservative audit reporting compensates less conservative } \\
\text { balance sheets where book values of assets exceed their } \\
\text { liquidation values/Multivariate test (logit and OLS) }\end{array}$ \\
\hline Kausar et al. (2017) & $\begin{array}{l}\text { US and UK/Public/1995-2002/823 } \\
\text { US and } 123 \text { UK first-time GCOs }\end{array}$ & $\begin{array}{l}\text { Investors in a creditor-friendly bankruptcy regime (UK) } \\
\text { react more adversely to a first-time GCO than investors in a } \\
\text { debtor-friendly regime (US)/Multivariate test (OLS) }\end{array}$ \\
\hline Myers et al. (2018) & $\begin{array}{l}\text { US/Public/2003-2014/897 new } \\
\text { GCOs }\end{array}$ & $\begin{array}{l}\text { Market responses to GCOs are statistically weak and smaller } \\
\text { in economic magnitude than has been suggested in prior } \\
\text { literature/Multivariate test (OLS) }\end{array}$ \\
\hline \multicolumn{3}{|c|}{ Line of research: Auditor independence and audit quality } \\
\hline $\begin{array}{l}\text { Schwartz and Menon } \\
\text { (1985) }\end{array}$ & $\begin{array}{l}\text { US/Public/1974-1982/132 failed } \\
\text { and } 132 \text { non-failed }\end{array}$ & $\begin{array}{l}\text { Greater tendency for failed firms to switch auditors than } \\
\text { non-failed firms; neither qualifications nor management } \\
\text { changes are associated with auditor displacement in failing } \\
\text { firms/Univariate analysis }\end{array}$ \\
\hline McKeown et al. (1991) & $\begin{array}{l}\text { US/Public/1974-1985/134 failed } \\
\text { and } 160 \text { non-failed }\end{array}$ & $\begin{array}{l}\text { Auditors are less likely to modify opinions of failed firms } \\
\text { that are large, have ambiguous probabilities of bankruptcy, } \\
\text { or have shorter lags between fiscal year end and audit } \\
\text { opinion dates/Multivariate test (logit) }\end{array}$ \\
\hline Pratt and Stice (1994) & US/243 responses & $\begin{array}{l}\text { The financial conditions of poorer firms are associated with } \\
\text { higher levels of litigation risk, more audit evidence, and } \\
\text { higher audit fees/Questionnaires to Big } 6 \text { partners }\end{array}$ \\
\hline Carcello et al. (1995) & US/Public/1972-1992/446 & $\begin{array}{l}\text { Increase in the propensity to modify bankruptcy-related } \\
\text { opinions after the issuance of SAS No. } 34 \text { but not after SAS } \\
\text { No. 59/Multivariate test (logit) }\end{array}$ \\
\hline
\end{tabular}


Table 1. Cont.

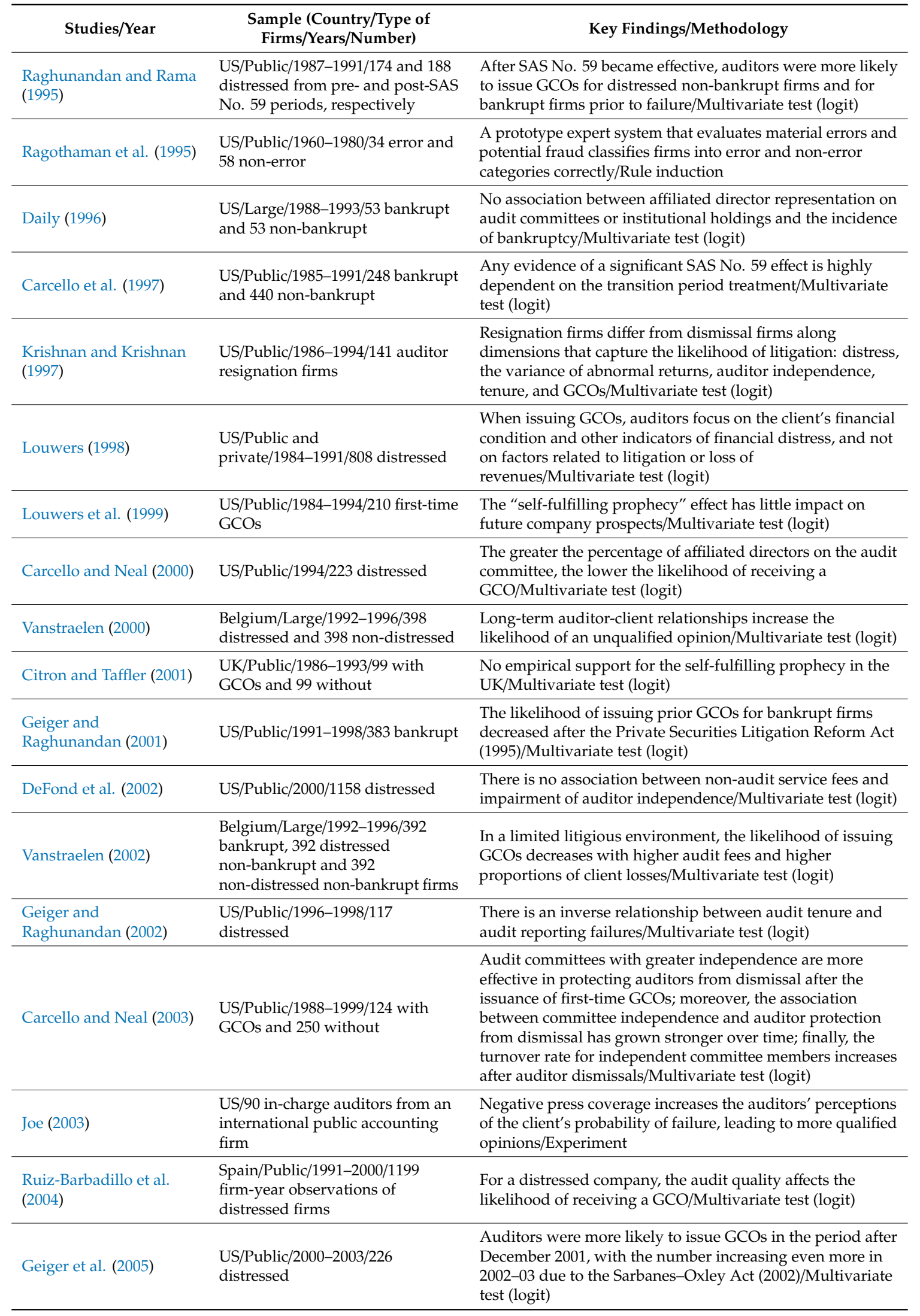


Table 1. Cont.

\begin{tabular}{|c|c|c|}
\hline Studies/Year & $\begin{array}{l}\text { Sample (Country/Type of } \\
\text { Firms/Years/Number) }\end{array}$ & Key Findings/Methodology \\
\hline Carey and Simnett (2006) & Australia/Public/1995/1021 & $\begin{array}{l}\text { For long audit partner tenure, there is a deterioration in } \\
\text { audit quality, measured by a lower propensity to issue } \\
\text { GCOs/Multivariate test (logit) }\end{array}$ \\
\hline Cunnigham (2006) & - & $\begin{array}{l}\text { Financial statement insurance could be a way to restructure } \\
\text { the auditing industry, so large audit firms can leave without } \\
\text { upsetting the financial system/Theoretical study }\end{array}$ \\
\hline $\begin{array}{l}\text { Knechel and Vanstraelen } \\
\text { (2007) }\end{array}$ & $\begin{array}{l}\text { Belgium/Large/1992-1996/309 } \\
\text { distressed bankrupt and } 309 \\
\text { distressed non-bankrupt }\end{array}$ & $\begin{array}{l}\text { Auditors are not less independent over time, nor do they } \\
\text { become better at predicting the failures of } \\
\text { companies/Multivariate test (logit) }\end{array}$ \\
\hline Carey et al. (2008) & $\begin{array}{l}\text { Australia/Public/1994-1997/68 } \\
\text { with first-time GCOs and } 68 \\
\text { without }\end{array}$ & $\begin{array}{l}\text { Audit switching is positively associated with the issuance of } \\
\text { GCOs; moreover, the issuance of a first-time GCO leads to a } \\
\text { loss of clients; however, there is no evidence of the } \\
\text { self-fulfilling prophecy/Multivariate test (logit) }\end{array}$ \\
\hline Robinson (2008) & US/Public/2001-2004/209 bankrupt & $\begin{array}{l}\text { There is a positive association between the level of tax } \\
\text { services fees and the likelihood of correctly issuing a GCO } \\
\text { prior to bankruptcy filing/Multivariate test (logit) }\end{array}$ \\
\hline Callaghan et al. (2009) & US/Public/2001-2005/92 bankrupt & $\begin{array}{l}\text { There is no connection between the issuance of GCOs and } \\
\text { audit and non-audit fees/Multivariate test (logit) }\end{array}$ \\
\hline $\begin{array}{l}\text { Feldmann and Read } \\
(2010)\end{array}$ & US/Public/2000-2008/565 bankrupt & $\begin{array}{l}\text { While the issuance of GCOs increased sharply in 2002-03 } \\
\text { when compared to 2000-01, the number decreased } \\
\text { immediately after returning to the pre-Enron } \\
\text { level/Multivariate test (logit) }\end{array}$ \\
\hline $\begin{array}{l}\text { Arnedo-Ajona et al. } \\
(2012)\end{array}$ & $\begin{array}{l}\text { Spain/Public and } \\
\text { private/1992-2002/236 bankrupt } \\
\text { and } 236 \text { non-bankrupt }\end{array}$ & $\begin{array}{l}\text { Significant increases in the probability of bankruptcy } \\
\text { following a GCO are limited to those cases in which the } \\
\text { opinion was considered unexpected/Multivariate test (OLS) }\end{array}$ \\
\hline Carey et al. (2012) & $\begin{array}{l}\text { Australia/Public/1995-1996 and } \\
\text { 2004-2005/142 with GCOs }\end{array}$ & $\begin{array}{l}\text { Auditors maintained the reporting accuracy of GCOs before } \\
\text { and after corporate collapses in 2001/Multivariate test (logit) }\end{array}$ \\
\hline Basioudis et al. (2012) & $\begin{array}{l}\text { US/Public/2000-2007 10,394 } \\
\text { firm-year observations of } \\
\text { distressed firms }\end{array}$ & $\begin{array}{l}\text { High non-audit fees affect auditor independence only when } \\
\text { audit tenure is long or when auditor quality is } \\
\text { poor/Multivariate test (logit) }\end{array}$ \\
\hline Chen et al. (2013) & $\begin{array}{l}\text { US/Public and } \\
\text { private/2000-2007/801 firm-year } \\
\text { observations with first-time GCOs } \\
\text { and } 11,528 \text { without }\end{array}$ & $\begin{array}{l}\text { The likelihood of receiving a GCO is negatively associated } \\
\text { with the level of insider trading/Multivariate test (logit, } \\
\text { probit, and OLS) }\end{array}$ \\
\hline $\begin{array}{l}\text { García-Blandón and } \\
\text { Argiles-Bosch (2013) }\end{array}$ & $\begin{array}{l}\text { Spain/Public/2001-2009/881 } \\
\text { firm-year observations }\end{array}$ & $\begin{array}{l}\text { The probability of issuing audit qualifications decreases with } \\
\text { audit tenure/Multivariate test (logit) }\end{array}$ \\
\hline Geiger et al. (2014) & US/Public/2004-2010/414 bankrupt & $\begin{array}{l}\text { The propensity of issuing a GCO prior to bankruptcy } \\
\text { increased after the GFC/Multivariate test (logit) }\end{array}$ \\
\hline $\begin{array}{l}\text { Rodríguez-López et al. } \\
\text { (2014) }\end{array}$ & $\begin{array}{l}\text { Galicia } \\
\text { (Spain)/Private/1990-1997/60 } \\
\text { distressed and } 60 \text { non-distressed }\end{array}$ & $\begin{array}{l}\text { Distress prediction models that use financial ratios show } \\
\text { higher performance rates than audit-based forecast } \\
\text { models/Multivariate test (MDA and logit) and neural } \\
\text { networks }\end{array}$ \\
\hline
\end{tabular}


Table 1. Cont.

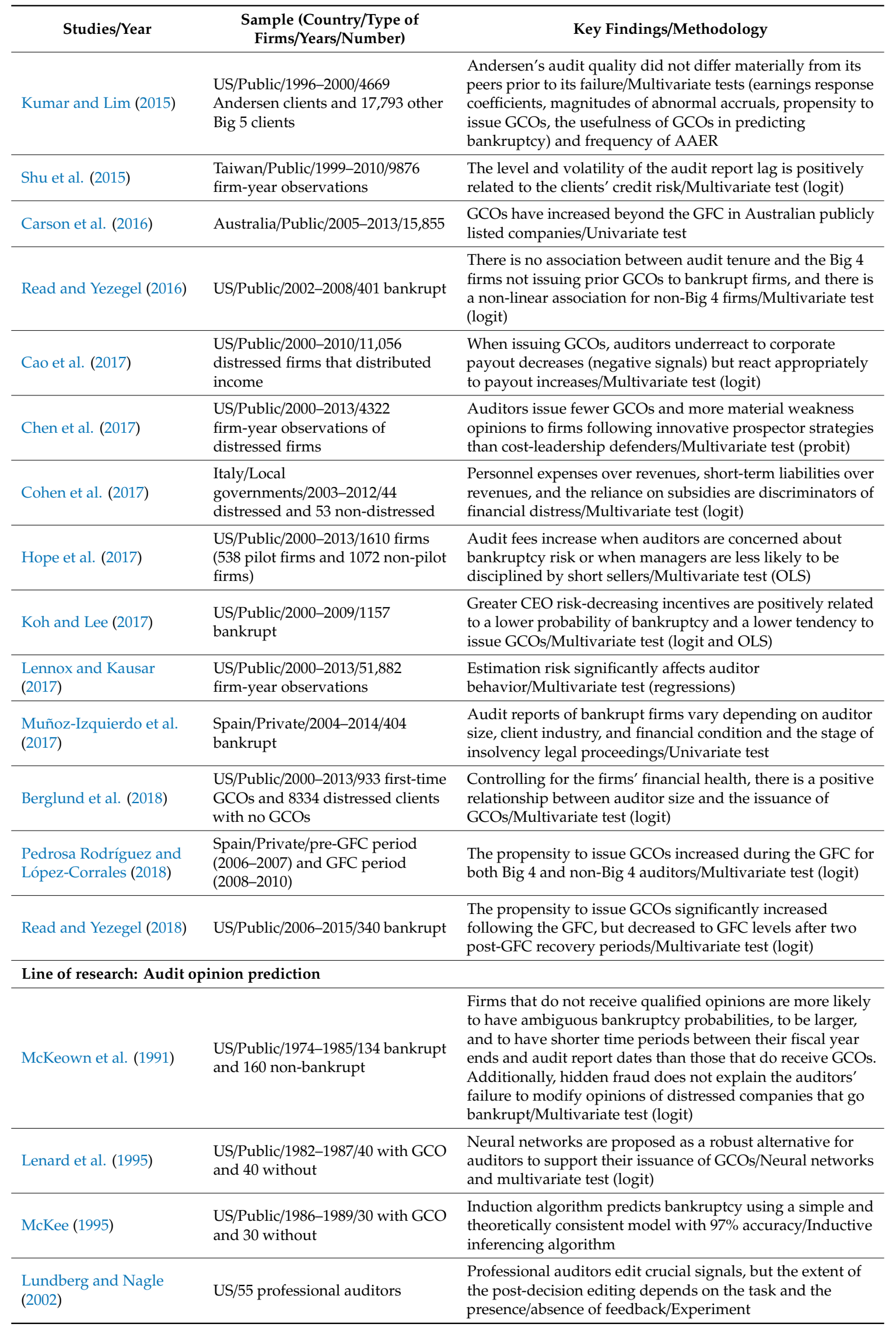


Table 1. Cont.

\begin{tabular}{|c|c|c|}
\hline Studies/Year & $\begin{array}{l}\text { Sample (Country/Type of } \\
\text { Firms/Years/Number) }\end{array}$ & Key Findings/Methodology \\
\hline Zdolsek and Jagric (2011) & $\begin{array}{l}\text { UK and } \\
\text { Ireland/Public/1997-2002/265 with } \\
\text { qualified opinion and 265 with } \\
\text { non-qualified }\end{array}$ & $\begin{array}{l}\text { Development of a model to identify qualified opinions using } \\
\text { accounting ratios/Multivariate test (logit) }\end{array}$ \\
\hline Cassell et al. (2013) & $\begin{array}{l}\text { US/Public/2004-2009/6702 } \\
\text { firm-year observations with } \\
\text { comment letter }\end{array}$ & $\begin{array}{l}\text { Low profitability, high complexity, engaging a small audit } \\
\text { firm, and weaknesses in governance are positively } \\
\text { associated with the receipt of SEC comment } \\
\text { letters/Multivariate tests (logit and OLS) }\end{array}$ \\
\hline Ittonen et al. (2017) & $\begin{array}{l}\text { US/Public/2003-2015/5146 } \\
\text { non-financial firms obtained from } \\
\text { Compustat }\end{array}$ & $\begin{array}{l}\text { GCOs should be issued when there is an } 8 \% \text { chance (or } \\
\text { higher) that the client is bankrupt/Shannon entropy from } \\
\text { information theory }\end{array}$ \\
\hline \multicolumn{3}{|c|}{ Line of research: Bankruptcy prediction using auditing } \\
\hline Casterella et al. (2000) & US/Public/1982-1992/100 bankrupt & $\begin{array}{l}\text { Auditors do not appear to be able to predict either } \\
\text { bankruptcy filings or resolutions/Multivariate analysis (logit) }\end{array}$ \\
\hline McKee (2003) & $\begin{array}{l}\text { US/Public/1991-1997/146 bankrupt } \\
\text { and } 145 \text { non-bankrupt }\end{array}$ & $\begin{array}{l}\text { Rough set models do not provide a significant comparative } \\
\text { advantage regarding prediction accuracy over auditors' } \\
\text { methodologies/Artificial intelligence (rough sets) }\end{array}$ \\
\hline Kim et al. (2008) & $\begin{array}{l}\text { Republic of Korea/1991-2003/35 } \\
\text { firms that recovered from financial } \\
\text { distress and } 24 \text { non-recovered }\end{array}$ & $\begin{array}{l}\text { Audit opinion, client risk, and client size are accurate } \\
\text { predictors of the survival prospects of distressed } \\
\text { firms/Multivariate test (logit) }\end{array}$ \\
\hline Altman et al. (2010) & $\begin{array}{l}\text { UK/Private/2000-2007/5.8 million } \\
\text { SMEs, of which } 66,000 \text { failed }\end{array}$ & $\begin{array}{l}\text { Creditors' legal actions, company filing histories, } \\
\text { comprehensive audit reports, and audit opinions contribute } \\
\text { to increasing the default prediction power of risk models for } \\
\text { SMEs/Multivariate test (logit) }\end{array}$ \\
\hline $\begin{array}{l}\text { Piñeiro-Sánchez et al. } \\
\text { (2012) }\end{array}$ & $\begin{array}{l}\text { Galicia } \\
\text { (Spain)/Private/1998-2008/101 } \\
\text { distressed and } 101 \text { non-distressed }\end{array}$ & $\begin{array}{l}\text { The accumulation of qualified opinions and high auditor } \\
\text { rotation rates are reliable measures of credit risk and } \\
\text { predictors of bankruptcy/Multivariate test (logit) }\end{array}$ \\
\hline $\begin{array}{l}\text { Piñeiro-Sánchez et al. } \\
\text { (2013) }\end{array}$ & $\begin{array}{l}\text { Galicia } \\
\text { (Spain)/Private/1998-2008/98 } \\
\text { distressed }\end{array}$ & $\begin{array}{l}\text { High auditor rotation, qualified reports, and non-compliance } \\
\text { with the publication deadlines of financial statements are } \\
\text { accurate indicators of financial distress/Multivariate test } \\
\text { (logit) }\end{array}$ \\
\hline $\begin{array}{l}\text { Van Peursem and Chan } \\
\text { (2014) }\end{array}$ & $\begin{array}{l}\text { New Zealand/Public/2001-2010/25 } \\
\text { failed and } 25 \text { non-failed }\end{array}$ & $\begin{array}{l}\text { There are significant differences between failing and } \\
\text { non-failing firms that can be detected using financial ratios } \\
\text { and audit data/Univariate analysis }\end{array}$ \\
\hline Appiah and Amon (2017) & $\begin{array}{l}\text { UK/Public/1994-2011/98 insolvent } \\
\text { and } 269 \text { solvent }\end{array}$ & $\begin{array}{l}\text { There is a negative association between meetings and the } \\
\text { independence of the audit committee/Multivariate test (logit) }\end{array}$ \\
\hline Armeanu et al. (2017) & Romania/Public/2013/69 & $\begin{array}{l}\text { Business failure is negatively influenced by CEO gender, } \\
\text { board size, and audit committee/Multivariate test (principal } \\
\text { components) }\end{array}$ \\
\hline Desai et al. (2017) & $\begin{array}{l}\text { US/Public/1995-2015/All } \\
\text { distressed firms in the SEC's } \\
\text { EDGAR database }\end{array}$ & $\begin{array}{l}\text { The survival rate of first-time GCOs is much lower using } \\
\text { delisting as a measure of financial viability than } \\
\text { bankruptcy/Search engine technology (textual analysis) }\end{array}$ \\
\hline
\end{tabular}

\subsubsection{Line of Research: Effects of Auditing}

Qualified opinions issued by auditors can have an impact in different ways. Audited financial statements with qualifications, or even Emphasis of Matter paragraphs, should be reviewed more carefully than unqualified audit reports (Stanisic et al. 2013). This advice is especially salient when qualifications are related to going concern uncertainties. For example, loan contracts include information regarding qualifications (Chen et al. 2016). However, it is not only qualifications that impact debt contracting. Going concern opinions can be interpreted as a communication of risk to the equity market (Blay et al. 2011), as they have an adverse effect on market prices (Menon and Williams 1994) and can cause an increase in the subsequent cost of capital (Amin et al. 2014). In particular, Kausar et al. (2017) found that the reaction to a first-time going concern opinion is more adverse in a creditor-friendly 
regime, such as that in the UK, than in a debtor-friendly regime, such as that in the US. However, recent evidence has shown that market reactions to going concern opinions are statistically weaker than has been suggested in prior literature (Myers et al. 2018).

\subsubsection{Line of Research: Auditor Independence and Audit Quality}

As evidenced in the review of the research, many studies have evaluated audit quality. Audit quality is one of the most relevant issues facing the auditing profession, and it depends on the auditor's competence and independence (Vanstraelen 2000). Competence relies on the auditor's knowledge and technological capabilities, and prior studies have shown that auditors can discover errors in the accounting system (Kida 1980).

Since audit quality is crucial for the effectiveness of the auditing profession (Vanstraelen 2000), factors that can impact independence, such as the pricing of audit services (Vanstraelen 2002; Robinson 2008; Callaghan et al. 2009; Stanley 2011; Basioudis et al. 2012; Hope et al. 2017), auditor tenure (Geiger and Raghunandan 2002; Carey and Simnett 2006; Knechel and Vanstraelen 2007; Read and Yezegel 2016), audit report lags (Shu et al. 2015), auditors' decisions to resign (Krishnan and Krishnan 1997), auditor switching (Schwartz and Menon 1985; Carey et al. 2008), or the composition of the audit committee (Carcello and Neal 2000, 2003) have been extensively studied. The issuance of going concern opinions has also been accepted as a measure of auditor independence and quality throughout the literature (Carey and Simnett 2006; Robinson 2008; DeFond and Zhang 2014; Koh and Lee 2017; Berglund et al. 2018). As auditor independence is difficult to assess directly, other common proxies used in the literature have been linked to the characteristics of clients, such as their size (McKeown et al. 1991; Aguiar-Díaz and Díaz-Díaz 2015), financial condition (Pratt and Stice 1994; Louwers et al. 1999; Muñoz-Izquierdo et al. 2017), strategies (Chen et al. 2017), corporate payouts (Cao et al. 2017), and CEO incentives (Koh and Lee 2017).

Although the empirical evidence is not unanimous, many studies have supported auditor independence. For instance, Louwers et al. (1999) confirmed that their assessments focused on the client's financial condition and other indicators of financial distress, and not on factors related to litigation risk or loss of clients. Additionally, DeFond et al. (2002) did not find an association between non-audit fees and impairment of independence, and Knechel and Vanstraelen (2007) stated that independence was maintained over time.

Additionally, audit quality has received increased attention after regulatory changes, corporate collapses, or economic crises. Carcello et al. (1995) found that qualified opinions increased after the issuance of Statement of Auditing Standard (SAS) No. 34 and not after SAS No. 59, while Feldmann and Read (2010) argued that the likelihood of going concern opinions increased sharply immediately after the Enron collapse, and Carey et al. (2012) showed that the likelihood of these opinions returned to pre-Enron level shortly thereafter. Pedrosa Rodríguez and López-Corrales (2018) posited that the propensity to issue going concern opinions increased during the recent global financial crisis in Spain, and similar evidence was found using publicly listed Australian firms by Carson et al. (2016). After the crisis, Geiger et al. (2014) indicated that going concern opinions kept increasing, but Read and Yezegel (2018) pointed out that they decreased to the crisis levels after two post recovery periods.

All this evidence shows that qualifications are interpreted as external signals of potential financial instabilities (Buchman and Collins 1998), and they also communicate information about audit quality (Piñeiro-Sánchez et al. 2013). The current study added more evidence to this line of research about the independence of auditors as they disclosed signals of bankruptcy in their audit reports before, during, and after the global financial crisis.

\subsubsection{Line of Research: Audit Opinion Prediction}

Prior research has shown that auditors signal bankruptcy in approximately half of the cases in which companies subsequently file for bankruptcy (McKee 2003; Laitinen and Laitinen 2009). 
Ittonen et al. (2017) suggested that going concern opinions should be issued when there is an $8 \%$ chance that the firm is bankrupt. McKeown et al. (1991) found that auditors issued less qualified opinions to larger firms, firms with shorter time lags between the fiscal year end and the audit opinion dates, and when the probability of bankruptcy was ambiguous. Additionally, empirical evidence has also shown that accounting data can be used to identify qualified opinions. Different methodologies, such as logistic regression (Zdolsek and Jagric 2011), neural networks (Lenard et al. 1995), or inductive inferencing algorithms (McKee 1995) have been applied for this purpose.

\subsubsection{Line of Research: Bankruptcy Prediction Using Auditing}

Prior works have found associations between audit quality, financial distress, and qualified reports (Blay 2005; Arnedo-Ajona et al. 2012). However, there seems to be no consensus on the accuracy of auditing information for predicting bankruptcy or the survival of firms. On one hand, it can be argued that auditors are not able to predict either bankruptcy filings or resolutions (Casterella et al. 2000). On the other hand, some researchers have agreed with the idea that differences between failing and non-failing firms might be detected using financial ratios and audit data (Van Peursem and Chan 2014). Some audit information contributes to an increase in default prediction power, such as the recurrent issuance of qualified opinions, high auditor rotation or lack of meetings, and the lack of independence of the audit committee (Kim et al. 2008; Altman et al. 2010; Piñeiro-Sánchez et al. 2012, 2013; Appiah and Amon 2017; Armeanu et al. 2017). The present study contributes to this research line by examining the predictive ability of information easily extracted from the audit report, which has resulted in variables never tested before in prediction literature.

\subsection{Research Question Development}

Although the auditing profession ensures the credibility of a firm's financial statements in the audit report, it seems that the audit report has not been well studied as a measure of bankruptcy prediction. Research opportunities remain in this area, and the present study has attempted to fill this gap.

The main role of external auditors is to guarantee the reliability of the financial statements presented by any company. Thus, it seems that the information included in audit reports is likely to improve the accuracy of bankruptcy prediction modeling. Based on this reasoning, audit report information should be incorporated as explanatory variables in statistical models. With this in mind, the research question to be investigated is specified as follows:

Research question: What information in the external audit report can accurately predict bankruptcy?

It is expected that information from the audit report will provide accurate bankruptcy predictive power, and therefore this work may complement previous studies. This is the first study to have applied the audit report in isolation as a bankruptcy predictor. Additionally, due to the vast number of audit report users (who do not necessarily need to be experts in auditing), the explanatory variables that could best anticipate the event of bankruptcy have been simplified. The variables investigated were the most accurate variables and were also the easiest to detect by any user of the report interested in a firm's insolvency. Finally, this study used novel techniques in the area of auditing for bankruptcy prediction: the non-parametric methodologies of the PART algorithm, random forest, and support vector machine.

\section{Methodology}

\subsection{Sample and the Dependent Variable}

As in previous bankruptcy studies, the present work applied a matched sample of bankrupt and non-bankrupt firms (Schwartz and Menon 1985; Carcello and Neal 2003; Knechel and Vanstraelen 2007; Blay et al. 2011). An ad-hoc sample of 808 Spanish private non-financial audited firms was manually 
selected and prepared from the entire population of firms in the Spanish Bureau Van Dijk (hereafter BVD) database. The sample was evenly divided between bankrupt and non-bankrupt firms.

A company was considered to be bankrupt if it had filed for bankruptcy protection (Piñeiro-Sánchez et al. 2013). Thus, all bankrupt firms included in the database that had filed for bankruptcy proceedings as of 30 January 2015 were identified (1821 firms), and their financial and audit data extracted from this source for the fiscal year prior to the bankruptcy filing date. The filing dates were also manually collected from the "Registro Público Concursal" (the official Spanish source of bankruptcy data), as they did not appear in the BVD database. All of the bankruptcy filing dates along the sample belonged to the 2004-2014 period. Out of the 1821 firms, the final bankrupt sample consisted of 404 observations, with the remaining firms being removed due to missing data.

Subsequently, each bankrupt observation was manually matched with a non-bankrupt firm. For each non-bankrupt firm, financial and audit data was extracted from the BVD database ${ }^{1}$ for the fiscal year prior to the bankruptcy filing date of its bankrupt pair. The matching procedure was performed according to year, firm size-using the measure of total assets-and industry, as in the prior literature (Schwartz and Menon 1985; Knechel and Vanstraelen 2007). Therefore, the process resulted in a total sample of 808 firms: 404 bankrupt, which were then matched with 404 non-bankrupt firms.

Following prior literature, a dummy variable was used (BANKRUPT) as the dependent variable (Piñeiro-Sánchez et al. 2013), because it represents the start of court bankruptcy proceedings, and therefore provides a legal, objective, and narrow definition of bankruptcy. The variable BANKRUPT takes the value of 1 if the firm has filed for bankruptcy proceedings; otherwise, it is 0 .

\subsection{Independent Variables: Audit Report Variables}

In this paper, the independent (or explanatory) variables of bankruptcy were related to the audit report. A summarized definition of all variables is presented in Table 2. The first variable tested was the audit opinion issued in the period prior to bankruptcy, or in the corresponding year for the non-bankrupt firms. The role of the opinion in predicting bankruptcy was examined, using a dummy variable (AUDIT_OP) with the following two categories: unqualified (0) and qualified (1) opinion. An opinion is unqualified when the auditor determines that the financial statement gives a true and fair view in accordance with the reporting framework used for the preparation of the annual accounts. An opinion is qualified when the auditor points out that the financial statement is materially misstated, or when the auditor is unable to obtain evidence regarding any transaction or disclosure. The audit opinion dummy variable was chosen as it has been the most studied audit variable in prior bankruptcy literature (Altman and McGough 1974; Laitinen and Laitinen 2009). It was expected that the opinion would contribute to distinguishing between bankrupt and non-bankrupt firms, according to prior findings (Piñeiro-Sánchez et al. 2013). According to Altman et al. (2010), there is a positive relationship between the likelihood of filing for bankruptcy and the issuance of a qualified report.

The second and third independent variables of this study represent the type of paragraph that auditors include in the report (if any). The dummy variable EMPHASIS takes the value of 1 if an Emphasis of Matter paragraph is included in the report, and 0 otherwise. Auditors disclose matter paragraphs when it is necessary to mention significant uncertainties, appropriately included in the notes to the financial statements. Emphasis sections point out fundamental matters for the users' understanding. These paragraphs do not qualify as the opinion, but represent concerns for the auditor and relevant signals regarding the likelihood of the firm's survival (Blay 2005).

Similarly, the categorical variable SCOPE_VIOLATIONS has a value of 1 when either a qualification regarding a scope violation or a qualification due to a violation of generally accepted accounting

1 The audit data available in the BVD database is a section called the "Auditor's opinion". It consists of a maximum of 991 characters of the report representing emphasis paragraphs, qualification paragraphs, or both. From this field, we extracted the audit opinion (unqualified or qualified), the type of paragraphs disclosed, and the number of comments in those paragraphs. We identified the comments manually by reading and labeling the content of each report. 
principles (GAAP) is included; 2 when both qualifications are issued in the report; and 0 when none are disclosed. It was hypothesized that the inclusion of any of these paragraphs in the audit report reveals a sign of possible bankruptcy, as indicated by the auditor. This expectation is in line with the rationale of the AUDIT_OP variable, because prior evidence suggests that prediction accuracy increases once the audit report (unqualified or qualified) is included in the estimation models (Altman et al. 2010).

Table 2. Classification and description of the audit report variables in this study.

\begin{tabular}{lll}
\hline AUDIT OPINION & AUDIT_OP & $\begin{array}{l}\text { Dummy variable with a value of } 1 \text { if the auditor's report } \\
\text { is qualified, and } 0 \text { if it is unqualified. }\end{array}$ \\
\hline TYPE OF PARAGRAPH & SMPHASIS & $\begin{array}{l}\text { Dummy variable with a value of } 1 \text { if the auditor's report } \\
\text { has an Emphasis of Matter paragraph, } 0 \text { otherwise. } \\
\text { Categorical variable with a value of } 0 \text { if no qualifications } \\
\text { appear in the report, } 1 \text { if the audit report has a } \\
\text { qualification due to a scope limitation or due a GAAP } \\
\text { violation, and } 2 \text { if the report shows both. }\end{array}$ \\
NUMBER OF COMMENTS NUMBER_COMM & $\begin{array}{l}\text { Categorical variable with a value of } 0 \text { if no comments are } \\
\text { disclosed in the report, and } 1 \text { to } 6 \text { according to the } \\
\text { number of comments shown. }\end{array}$ \\
\hline
\end{tabular}

Table 2 summarizes the independent variables used in this study and the audit report variables.

Furthermore, not only did was the type of paragraphs disclosed in the audit report tested, but also the number of comments mentioned by auditors in them. A categorical variable (NUMBER_COMM) was incorporated that had the value of 0 when no comments were disclosed, and otherwise 1 to 6 in agreement with the number of comments shown. Six comments was the maximum number found in a few firms in the database. Most comments were related to accounting elements, such as the valuation of assets, liabilities, accumulated losses, or negative working capital, but auditors also write about regulatory issues, concerns regarding markets in which firms operate, or companies being involved in legal processes ${ }^{2}$. A positive association was hypothesized between an increase in the number of comments and the propensity to file for bankruptcy, which was based on the idea that more comments might point to higher chances of bankruptcy and more concerns for users when reading the audit report. A contribution was made to the literature by adding this variable to the estimation models as, to our knowledge, the predictive power of the accumulation of auditor comments has not been tested thus far.

\subsection{Artificial Intelligence Methodology: The PART Algorithm}

Despite the popularity of parametric models (such as the commonly used multivariate discriminant analysis or the logit regression model) for bankruptcy prediction, another current research approach to tackle financial problems is based on non-parametric techniques such as artificial intelligence

2 To illustrate the process of identifying the comments in the audit report, here is one example of a firm included in our sample. This firm filed for bankruptcy in 2008 and issued an unqualified audit report with an emphasis on the matter paragraph in the same year. According to the BVD database, this paragraph said: "The company incurred a net loss of 3128 thousand of euros during the year ended 31 December 2008. Also, as of that date, its current liabilities exceeded its total assets so that the company may be unable to convert its assets into funds that can be used to meet its financial obligations. Additionally, as stated in Note 16 in the financial statements, the company holds significant investments in group companies under serious financial distress. These events or conditions indicate that a material uncertainty exists that may cast significant doubt on the company's ability to continue as a going concern. Although the financial statements were prepared on a going concern basis, the company may be unable to realize its assets, specially the tax credit, and discharge its liabilities in the normal course of business." Therefore, the comments of the report basically total six in number: accumulated losses, negative working capital, short-term and long-term financial investments, going concern, and deferred tax assets. These are the comments that we took into consideration in our sample, so the independent variable NUMBER_COMM for this firm took the value of six. For this firm, the other three independent dummy variables of the study took the following values: $A U D I T \_O P$ value of 0 (unqualified), EMPHASIS takes the value of 1 (matter paragraph disclosed), and SCOPE_VIOLATIONS is 0 (no qualifications). 
(Calderon and Cheh 2002; Zięba et al. 2016; Amani and Fadlalla 2017). While parametric techniques have shown satisfactory results, they have a drawback when applied to real bankruptcy data, as some hypotheses required are not satisfied (especially if outliers exist). However, artificial intelligence techniques, which are non-parametric, do not require the data to satisfy any concrete assumptions. This advantage allows them to predict bankruptcy more accurately. Indeed, artificial intelligence methods have already been used to explain insolvency risk (Kumar and Ravi 2007; Wu 2010; Koyuncugil and Ozgulbas 2012; Kirkos 2015) and prior research has also applied these methods for anticipating going concern issues (Lenard et al. 1995; Yeh et al. 2014).

In this paper, the PART algorithm was used as the main artificial intelligence technique. Additionally, the validity of the results was tested by applying two other machine learning methodologies, namely random forest and support vector machine, as robustness checks.

The PART algorithm is a rule induction classifier developed by Frank and Witten (1998) that generates rules by incorporating a modified form of the J48 decision tree and eliminating some of the paths found in an initial decision tree structure. This algorithm builds partial decision trees instead of fully explored ones. Once the algorithm finds the partial tree, the tree-building stops and a rule is generated with the leaf that represents the greatest number of situations. Due to the fact that it is based on partial decision trees, the main advantage of the PART algorithm is its simplicity. However, its performance is similar to that of other machine learning algorithms. Consequently, this explicative technique was chosen because of the simplicity of its rules, with no loss of accuracy. The results are easier to interpret when compared to other classifiers as they are expressed in logical if/else statements (Díaz-Martínez et al. 2009). Additionally, the usefulness of this methodology has been corroborated in business studies (Camacho-Miñano et al. 2015), although it has not been applied before for bankruptcy prediction using audit report variables.

The rules created by the PART algorithm classify objects into decision classes depending on a series of variables or conditions. These rules are expressed in logical statements with the following form: IF $<$ conditions are fulfilled $>$ THEN $<$ the object belongs to a given decision class $>$.

In this study, the objects were firms, the two decision classes were bankrupt and non-bankrupt, and the conditions were all audit report variables or independent variables. Thus, the PART algorithm was applied to classify firms (objects) into bankrupt and non-bankrupt (decision classes) depending on a set of audit report variables (conditions).

\section{Results and Discussion}

\subsection{Summary Statistics}

Summary statistics of the sample are provided in Table 3. Bankrupt and non-bankrupt firms had the same frequency per industry due to the matching technique used. The total sample included a variety of industries, with construction and real-estate firms making up the largest group (35\%), mainly due to the impact of the housing bubble during the global financial crisis in Spain (Conefrey and Gerald 2010). Accordingly, along with the matching procedure, this study controlled for firm size in its statistical analyses, by measuring by the firms' total assets in thousands of euros.

Table 3. Descriptive statistics.

\begin{tabular}{ccccc}
\hline \multicolumn{5}{c}{ Frequency of Industries by Bankruptcy Classification } \\
\hline & Bankrupt firms & Non-bankrupt firms & Total & Total (\%) \\
\hline Construction and real-estate & 141 & 141 & 282 & $35 \%$ \\
Manufacturing & 110 & 110 & 220 & $27 \%$ \\
Commercial & 79 & 79 & 158 & $20 \%$ \\
Services & 70 & 70 & 140 & $17 \%$ \\
Primary & 4 & 4 & 8 & $1 \%$ \\
Total & 404 & 404 & 808 & $100 \%$ \\
\hline
\end{tabular}


Table 3. Cont.

\begin{tabular}{|c|c|c|c|c|}
\hline \multicolumn{5}{|c|}{ Means and Standard Deviations by Bankruptcy Classification } \\
\hline & \multicolumn{2}{|c|}{ Bankrupt firms } & \multicolumn{2}{|c|}{ Non-bankrupt firms } \\
\hline & Mean & S.D. & Mean & S.D. \\
\hline Age (years) & 22 & 13 & 23 & 14 \\
\hline Size (total assets) & 84,352 & 276,969 & 84,431 & 293,514 \\
\hline WCTA & -0.090 & 0.401 & 0.239 & 0.307 \\
\hline EBITTA & -0.169 & 0.329 & 0.026 & 0.104 \\
\hline BVETL & 0.278 & 1.098 & 1.728 & 3.015 \\
\hline \# of obs. & \multicolumn{2}{|c|}{404} & \multicolumn{2}{|c|}{404} \\
\hline
\end{tabular}

Table 3 presents the summary statistics of the sample. The total sample comprised 808 firms, 404 of which had filed for bankruptcy legal proceedings. The rest, or non-bankrupt group, were manually selected to match the year, size (total assets), and industry of one of the bankrupt observations. Industries of the sample were created based on NACE (Nomenclature of Economic Activities) codes. The age of the sample was expressed in years and the size in thousands of euros. WCTA stands for "Working capital divided by total assets", EBITTA for "Earnings before interest and taxes divided by total assets", and BVETL for "Book value of equity divided by total liabilities". Data used to calculate the financial ratios was winsorized at $1 \%$ and $99 \%$. Finally, \# of obs. is the number of observations.

Regarding the financial condition of the sample, bankrupt companies are generally more illiquid (lower working capital to total assets ratio), less profitable (lower return on assets ratio), and more leveraged (higher book value of equity to total liabilities ratio) than non-bankrupt firms, which is consistent with prior studies (Bellovary et al. 2007; Tascón-Fernández and Castaño-Gutiérrez 2012; Altman et al. 2017).

\subsection{The Results of the PART Algorithm}

\subsubsection{PART Algorithm: Model 1}

Results of the estimation models using the PART algorithm are presented below. Model 1 is based on the audit opinion (AUDIT_OP) as the only explanatory variable of bankruptcy (see Figure 1). The classification power of the model was $68.20 \%$ (31.80\% incorrectly classified cases). According to this model, this dummy variable classified 513 firms as non-bankrupt with $36 \%$ error (183 errors) and 295 as bankrupt (25\% error). This result suggests that, in isolation, the audit opinion anticipated the financial condition of two-thirds of the sample accurately. Although this prediction does not appear to be very precise, it is relevant, considering that the model only includes one variable. This evidence complements previous studies where the audit opinion was a bankruptcy predictor (Hopwood et al. 1989; Laitinen and Laitinen 2009; Altman et al. 2010; Piñeiro-Sánchez et al. 2012, 2013) and those that interpreted qualifications as external signals of potential financial instabilities (Buchman and Collins 1998). However, this variable solely has never before been used 23 March 2019, probably due to the number of incorrectly classified cases obtained. In the following models, more explanatory variables were included, to increase the predictive accuracy.

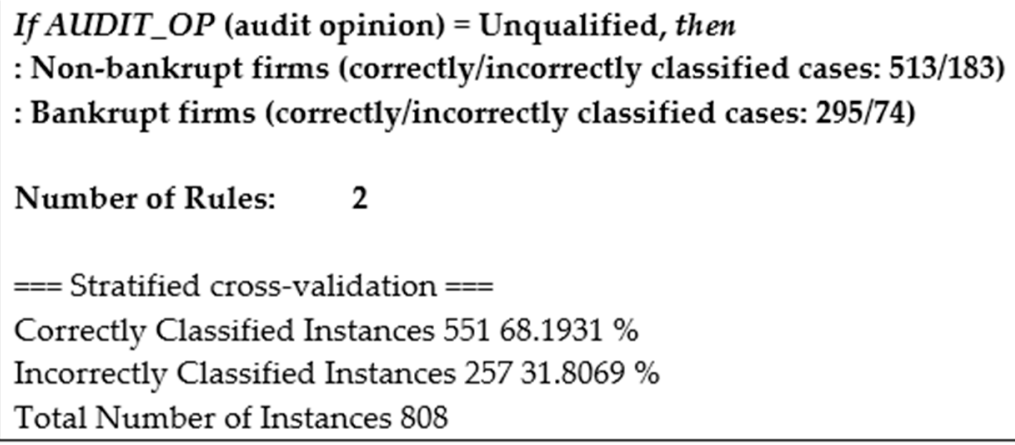

Figure 1. Model 1: The audit opinion PART model. 


\subsubsection{PART Algorithm: Model 2}

As the prediction was relatively low in Model 1, Model 2 added the two dummy variables of the type of paragraphs disclosed in the audit report (EMPHASIS and SCOPE_VIOLATIONS) to the initial model, when those paragraphs existed in the firms (see Figure 2). As mentioned previously, auditors place their comments in the audit report, either in the Emphasis of Matter sections that do not qualify the opinion (EMPHASIS) or in qualification paragraphs (SCOPE_VIOLATIONS). In Model 2 , the predictive power increased to $76.49 \%$ (23.51\% incorrectly classified cases). This result showed the relevance of the type of paragraph for explaining bankruptcy, as the prediction improved by $8 \%$ when compared to Model 1. Even more importantly, it provided evidence of the importance of Matter sections when predicting bankruptcy. The existence of qualifications did not appear in the model as it is embedded in the qualified opinion (when the opinion is qualified, a qualification paragraph is disclaimed), that is, when the dummy variable AUDIT_OP takes the value of 1.

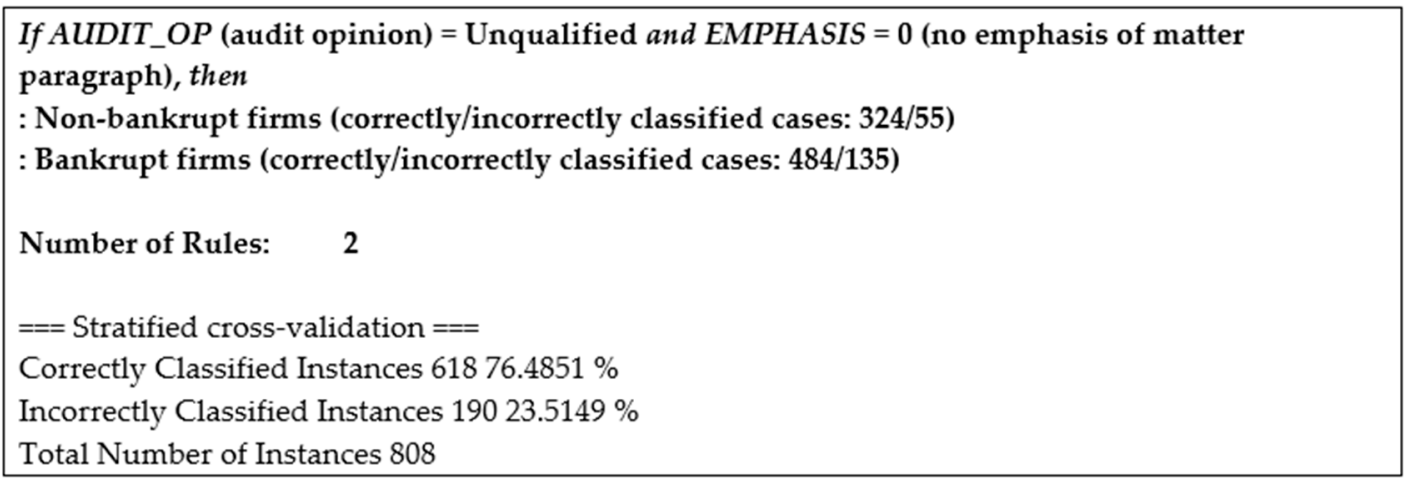

Figure 2. Model 2: The audit opinion and type of paragraphs PART model.

As per Model 2, if the audit opinion was unqualified $\left(A U D I T \_O P=0\right)$, the viability of the firm was determined by the existence of a Matter section. Without an Emphasis of Matter paragraph, the model classified the firms as non-bankrupt $\left(A U D I T \_O P=0\right.$ and EMPHASIS $=0$ ) in 324 cases ( $17 \%$ error). Interestingly, even when the opinion was unqualified, the algorithm classified a firm as bankrupt when a Matter section was disclosed (AUDIT_OP $=0$ and EMPHASIS $=1$ ), and this rule codified 484 firms ( $28 \%$ error). This empirical evidence validates prior studies that suggest that auditors issued unqualified reports to some bankrupt firms during the recent global financial crisis (Sikka 2009). However, the role of external auditors during that period could not be fully questioned, as their main task was to guarantee the reliability of the firms' financial statements and, according to the results of this study, were at least issuing Matter sections emphasizing their financial concerns about soon-to-be-bankrupt firms.

\subsubsection{PART Algorithm: Model 3}

In Model 3, the number of comments in the paragraphs was aggregated to the PART algorithm as a new independent and categorical variable (see Figure 3). This model strongly codified firms as non-bankrupt when there were no paragraphs, so in the absence of comments NUMBER_COMM $=0$. This rule classified 324 firms as non-bankrupt (17\% error). The same classification was provided by the algorithm when one comment was disclosed but the opinion was unqualified, so the comment was disclosed in a Matter section (55 firms classified as non-bankrupt, $20 \%$ error). 


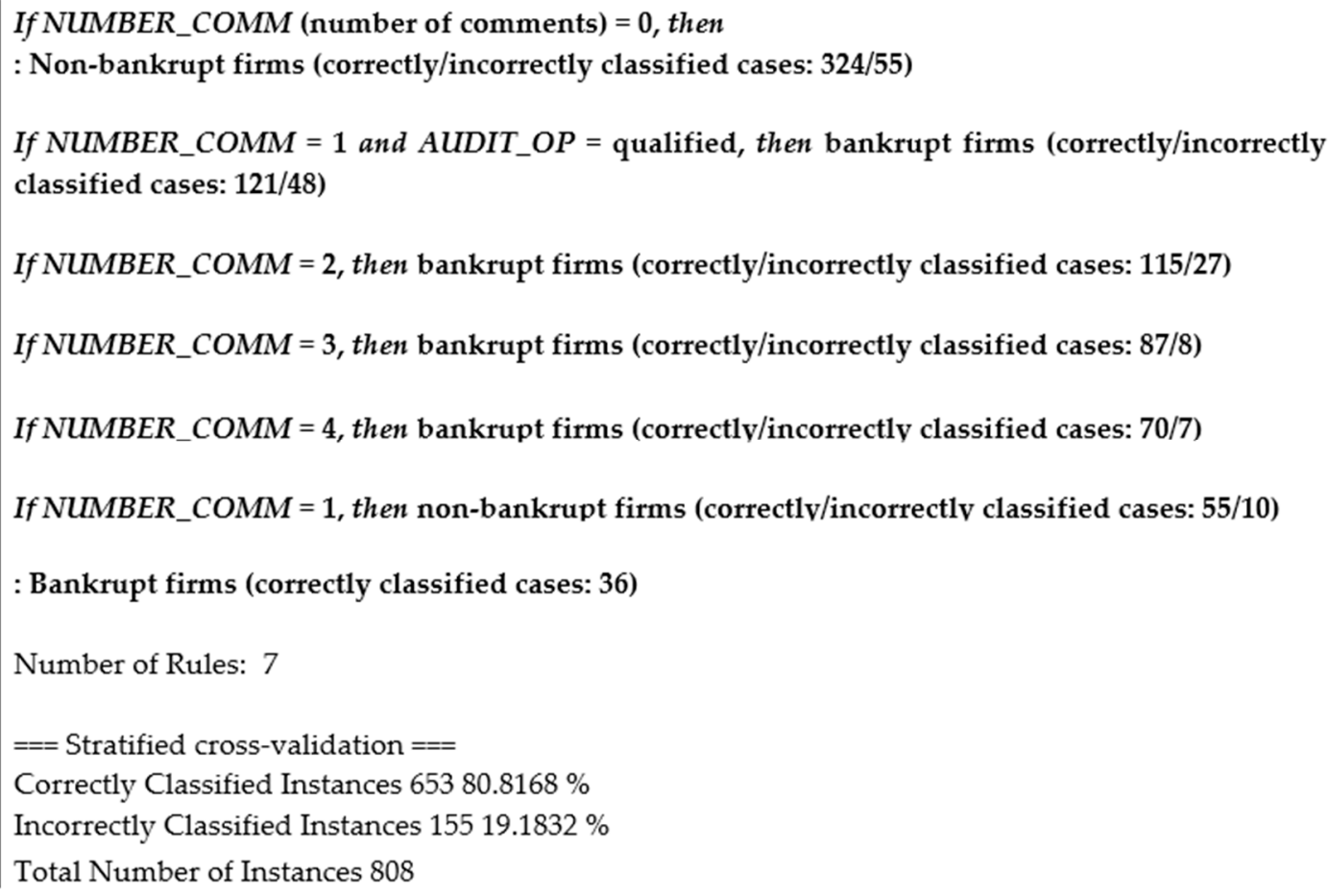

Figure 3. Model 3: The audit opinion, type of paragraphs, and number of comments in the PART model.

However, with one comment in a qualification paragraph (NUMBER_COMM = 1 and AUDIT_OP $=1$ ), the classification already moved to bankruptcy (121 bankrupt firms, $40 \%$ error). From one comment onwards (NUMBER_COMM = 2; 3; 4), there was a prevailing discrimination toward bankruptcy with a low percentage of error. In line with prior studies that incorporated different qualifications in their estimations (Hopwood et al. 1989; Piñeiro-Sánchez et al. 2012), the inclusion of the number of comments increased the predictive ability of the model (in this study, the classification went up $5 \%$, from $76.49 \%$ to $80.82 \%$ ), indicating that if auditors disclose several concerns in their reports, it is very plausible that the viability of the firm is being questioned. Thus, these results indicate that there is a positive relationship between the propensity of a firm to file for bankruptcy and a high number of comments disclosed in the audit report. The evidence from this model complemented the prior literature because this is the first time in which the accumulation of auditors' comments was tested for bankruptcy predictive purposes.

In conclusion, after analyzing the findings of the three models, the research question could be answered. The audit report information-mainly consisting of the easily extracted variables of the audit opinion, the disclosure of a Matter paragraph, and the number of comments shown-represents accurate measures for predicting bankruptcy. Thus, there is a positive relationship between these audit report disclosures and the propensity of a firm to file for bankruptcy.

\subsubsection{Robustness: Random Forest and SVM}

To ensure the reliability of the empirical evidence in this study, two robustness checks were performed, using other artificial intelligence methodologies. These checks examined whether the correctly classified instances remained constant, using random forest and support vector machine. These two methods were chosen because they are widely applied in the bankruptcy and going concern prediction literature (Min and Lee 2005; Min et al. 2006; Yeh et al. 2014). Random Forest is a machine learning classifier that uses a combination of independent decision trees to model data (Yeh et al. 2014). The trees are built using bootstrap samples, not all data are applied to build a tree, and features are randomly selected at each node. Therefore, Random Forest is one of the most accurate and 
efficient classifiers, even in large datasets with missing data, as it generates an unbiased estimate of the generalization error as the forest building progresses.

Support vector machine is a learning algorithm that applies a linear model to implement nonlinear classes through vectors into a high-dimensional space (Min and Lee 2005). It finds a maximum margin hyperplane that provides the maximum separation between decision classes. The support vectors are the examples used for defining the classes, and are the closest to the hyperplane. Support vector machine has been used in bankruptcy prediction because the results are easy to analyze, less theory-driven and more data-driven, and more distribution-free than conventional statistical techniques (Min and Lee 2005).

Motivated by these studies, random forest and support vector machine were applied to check the robustness of the results of the PART algorithm. The untabulated evidence of this study suggests that the confusion matrixes obtained by the random forest and the support vector machine revealed the same percentages of correctly-classified cases as the PART algorithm. For Models 1, 2, and 3, the percentages of classification accuracy were $68.2 \%, 76.5 \%$, and $80.8 \%$, respectively. Therefore, according to other machine learning algorithms, the ability to anticipate bankruptcy for the audit report variables of this study was robust. When auditors issue their reports, users may pay attention to the type of opinion, the existence of a Matter paragraph, and other comments included in qualification paragraphs, as these pieces of information represent signs of a firm's bankruptcy.

\section{General Conclusions}

The aim of this paper was to examine the explanatory power of the external audit report when predicting the bankruptcy situation of firms. New prediction models were introduced using artificial intelligence methodologies - the PART algorithm, random forest, and support vector machine-which had never been applied before in bankruptcy prediction models using data from audit reports. The evidence indicates that the information extracted from the audit report is useful for analyzing the probability of filing for bankruptcy and anticipating precarious financial conditions with high accuracy. Specifically, using the PART algorithm, classification rules were found where the most significant variables that distinguished between bankrupt and non-bankrupt firms were the audit opinion, the Matter sections disclosed in the audit reports, and the number of comments included in the Matter sections and qualification paragraphs. This evidence shows the positive relationship between the tendency of a firm to file for bankruptcy and the issuance of a qualified report with a high number of comments disclosed by the auditors. Interestingly, our results even corroborated the positive relationship between the bankruptcy filing and an unqualified report issued with comments disclosed in a matter paragraph.

Some implications can be drawn from these results. A contribution was made to the literature of bankruptcy prediction. This is the first study that used three non-parametric methodologies with only variables extracted from the audit report (the audit opinion, type of paragraphs, and number of comments in the report) to forecast a bankruptcy situation. The only study that was closely related to the present study was that by Muñoz-Izquierdo et al. (2019). However, the objectives of both papers were different. Muñoz-Izquierdo et al. (2019) used the content of the audit report to explain the specific causes of business failure, that is, they focused on justifying the reasons why firms failed, such as internal causes like accumulated losses or high debts, or external causes such as changes in the market in which they operate or policy changes that affect them. The current paper looked for an accurate percentage of prediction, and not the particular causes of the bankruptcy. It also attempted to find the minimum number of variables from the audit report that achieved the most accurate bankruptcy predictive power possible, and these variables also needed to be the easiest for any user to obtain without any specific knowledge. Therefore, the current work is a follow-up study of the aforementioned paper, with practical implications for the users of the report. A user can strongly benefit from this study, because it found that there was no need to be an expert in the accounting and auditing domains to be able to use the audit report to detect if a firm was going bankrupt. Simply by 
identifying the type of opinion, whether or not a Matter section was disclosed by the auditor, and the number of comments included in the section or in a qualification paragraph, any user could quickly and easily predict the chances of bankruptcy with the same accuracy as if they had scrutinized the complete audit report. Therefore, this result may save costs in terms of time and effort to financial analysts, creditors, firms' stakeholders, and other potential users of the audit reports.

Finally, the auditing profession might also benefit from this paper because the results confirmed that, during the global financial crisis, there was an important number of bankrupt firms that issued qualified reports or, at least, a warning in a Matter section about their imminent failure, whereas non-bankrupt companies issued unqualified reports. Thus, even though the role of auditors is to ensure the reliability of the financial information provided to stakeholders, the audit report can also be a "first glance" signal to evaluate a firm's probability of bankruptcy.

The limitations of this study are mainly related to the sample. First, the non-bankrupt group was selected based on a matching process, using the variables of firm size, year, and industry, in accordance with prior literature. Nevertheless, it seems reasonable to think that other variables could have been chosen. Second, this study focused on Spanish private non-financial firms, so some results might have been driven by the specific socio-demographic characteristics of the sample. For instance, due to the Spanish context, the frequency of firms in the different industries of the sample varied significantly. For comparison purposes, future research could focus on an extension of the study to other regulatory contexts and periods of time. Although this line of research could lead to very interesting results, the preparation of the dataset might be time consuming given that every audit report must be manually codified.

Author Contributions: Conceptualization, N.M.-I. and M.d.-M.C.-M.; Data curation, N.M.-I.; Formal analysis, N.M.-I. and M.d.-M.C.-M.; Investigation, N.M.-I.; Methodology, software and validation, M.-J.S.-V.; Project administration and supervision, M.-d.-M.C.-M. and D.P.-E.; Writing—original draft, N.M.-I. and M.-d.M.C.-M.; Writing-review \& editing, All.

Funding: This research received no external funding.

Acknowledgments: This paper is part of an ongoing project of the Research Group UCM 950025 “Risk in insurance, finance, financial distress, and entrepreneurship". We wish to thank our universities for their support and we are also very grateful to the participants of the EAA 40th Annual Congress 2017 for their helpful comments.

Conflicts of Interest: The authors declare no conflict of interest.

\section{References}

Aguiar-Díaz, Inmaculada, and Nieves L. Díaz-Díaz. 2015. Audit quality, second-tier and size: Effect on the Spanish private distressed firms. Spanish Journal of Finance and Accounting 44: 24-46.

Altman, Edward I. 2018. Applications of distress prediction models: What have we learned after 50 years from the Z-Score models? International Journal of Financial Studies 6: 70. [CrossRef]

Altman, Edward I., and Thomas P. McGough. 1974. Evaluation of a company as a going-concern. Journal of Accountancy 138: 50-57.

Altman, Edward I., Gabriele Sabato, and Nicholas Wilson. 2010. The value of non-financial information in small and medium-sized enterprise risk management. Journal of Credit Risk 2: 95-127. [CrossRef]

Altman, Edward I., Małgorzata Iwanicz-Drozdowska, Erkki K. Laitinen, and Arto Suvas. 2017. Financial distress prediction in an international context: A review and empirical analysis of Altman's Z-Score model. Journal of International Financial Management and Accounting 28: 131-71. [CrossRef]

Amani, Farzaneh A., and Adam M. Fadlalla. 2017. Data mining applications in accounting: A review of the literature and organizing framework. International Journal of Accounting Information Systems 24: 32-58. [CrossRef]

Amin, Keval, Jagan Krishnan, and Joon Sun Yang. 2014. Going concern opinion and cost of equity. Auditing: A Journal of Practice and Theory 33: 1-39. [CrossRef]

Appiah, Kingsley Opoku, and Chizema Amon. 2017. Board audit committee and corporate insolvency. Journal of Applied Accounting Research 18: 298-316. [CrossRef] 
Armeanu, Daniel Ştefan, Georgeta Vintilă, Ştefan Cristian Gherghina, and Dan Cosmin Petrache. 2017. Approaches on correlation between board of directors and risk management in resilient economies. Sustainability 9: 173. [CrossRef]

Arnedo-Ajona, Laura, Fermín Lizarraga-Dallo, Santiago Sánchez-Alegría, and Emiliano Ruiz-Barbadillo. 2012. User's expectations before audit going concern opinions. Empirical evidence of self-fulfilling prophecy in the Spanish case. Spanish Journal of Finance and Accounting 41: 263-89.

Balcaen, Sofie, and Hubert Ooghe. 2006. 35 years of studies on business failure: An overview of the classic statistical methodologies and their related problems. The British Accounting Review 38: 63-93. [CrossRef]

Barth, Mary E., William H. Beaver, and Wayne R. Landsman. 1998. Relative valuation roles of equity book value and net income as a function of financial health. Journal of Accounting and Economics 25: 1-34. [CrossRef]

Basioudis, Ilias G., Ferdinand A. Gul, and Anthony C. Ng. 2012. Non-Audit fees, Auditor Tenure, and Auditor Independence. Working Paper. Available online: https://papers.ssrn.com/sol3/papers.cfm?abstract_id= 2043311 (accessed on 3 April 2019).

Bauweraerts, Jonathan. 2016. Predicting bankruptcy in private firms: Towards a stepwise regression procedure. International Journal of Financial Research 7: 147-53. [CrossRef]

Bellovary, Jodi L., Don E. Giacomino, and Michael D. Akers. 2007. A review of bankruptcy prediction studies: 1930 to present. Journal of Financial Education 33: 1-42.

Berglund, Nathan R., John Daniel Eshleman, and Peng Guo. 2018. Auditor size and going concern reporting. Auditing: A Journal of Practice $\mathcal{E}$ Theory 37: 1-25.

Blay, Allen D. 2005. Independence threats, litigation risk, and the auditor's decision process. Contemporary Accounting Research 22: 759-89. [CrossRef]

Blay, Allen D., Marshall A. Geiger, and David S. North. 2011. The auditor's going-concern opinion as a communication of risk. Auditing: A Journal of Practice and Theory 30: 77-102. [CrossRef]

Buchman, Thomas A., and Denton Collins. 1998. Uncertainty about litigation losses and auditors' modified audit reports. Journal of Business Research 43: 57-63. [CrossRef]

Calderon, Thomas G., and John J. Cheh. 2002. A roadmap for future neural networks research in auditing and risk assessment. International Journal of Accounting Information Systems 3: 203-36. [CrossRef]

Callaghan, Joseph, Mohinder Parkash, and Rajeev Singhal. 2009. Going-concern audit opinions and the provision of nonaudit services: Implications for auditor independence of bankrupt firms. Auditing: A Journal of Practice and Theory 28: 153-69. [CrossRef]

Camacho-Miñano, Maria-del-Mar, Maria-Jesus Segovia-Vargas, and David Pascual-Ezama. 2015. Which characteristics predict the survival of insolvent firms? An SME reorganization prediction model. Journal of Small Business Management 53: 340-54. [CrossRef]

Cao, Jian, Thomas R. Kubick, and Adi N.S. Masli. 2017. Do corporate payouts signal going-concern risk for auditors? Evidence from audit reports for companies in financial distress. Review of Quantitative Finance and Accounting 49: 599-631. [CrossRef]

Carcello, Joseph V., and Terry L. Neal. 2000. Audit committee composition and auditor reporting. The Accounting Review 75: 453-67. [CrossRef]

Carcello, Joseph V., and Terry L. Neal. 2003. Audit committee characteristics and auditor dismissals following "new" going-concern reports. The Accounting Review 78: 95-117. [CrossRef]

Carcello, Joseph V., Dana R. Hermanson, and H. Fenwick Huss. 1995. Temporal changes in bankruptcy-related reporting. Auditing: A Journal of Practice and Theory 14: 133-43.

Carcello, Joseph V., Dana R. Hermanson, and H. Fenwick Huss. 1997. The effect of SAS No. 59: How treatment of the transition period influences results. Auditing: A Journal of Practice and Theory 16: 114-23.

Carey, Peter, and Roger Simnett. 2006. Audit partner tenure and audit quality. The Accounting Review 81: 653-76. [CrossRef]

Carey, Peter J., Marshall A. Geiger, and Brendan T. O'Connell. 2008. Costs associated with going-concern-modified audit opinions: An analysis of the Australian audit market. Abacus 44: 61-81. [CrossRef]

Carey, Peter, Stuart Kortum, and Robyn Moroney. 2012. Auditors' going-concern-modified opinions after 2001: Measuring reporting accuracy. Accounting and Finance 52: 1041-59. [CrossRef]

Carson, Elizabeth, Neil Fargher, and Yuyu Zhang. 2016. Trends in auditor reporting in Australia: A synthesis and opportunities for research. Australian Accounting Review 26: 226-42. [CrossRef] 
Cassell, Cory A., Lauren M. Dreher, and Linda A. Myers. 2013. Reviewing the SEC's review process: 10-K comment letters and the cost of remediation. The Accounting Review 88: 1875-908. [CrossRef]

Casterella, Jeffrey R., Barry L. Lewis, and Paul L. Walker. 2000. Modeling the audit opinions issued to bankrupt companies: A two-stage empirical analysis. Decision Sciences 31: 507-30. [CrossRef]

Cenciarelli, Velia Gabriella, Giulio Greco, and Marco Allegrini. 2018. External audit and bankruptcy prediction. Journal of Management and Governance 22: 1-28. [CrossRef]

Charitou, Andreas, Neophytos Lambertides, and Lenos Trigeorgis. 2007. Earnings behaviour of financially distressed firms: The role of institutional ownership. Abacus 43: 271-96. [CrossRef]

Chen, Kevin C. W., and Bryan K. Church. 1996. Going concern opinions and the market's reaction to bankruptcy filings. The Accounting Review 71: 117-28.

Chen, Chen, Xiumin Martin, and Xin Wang. 2013. Insider trading, litigation concerns, and auditor going-concern opinions. The Accounting Review 88: 365-93. [CrossRef]

Chen, Peter F., Shaohua He, Zhiming Ma, and Derrald Stice. 2016. The information role of audit opinions in debt contracting. Journal of Accounting and Economics 61: 121-44. [CrossRef]

Chen, Yu, John Daniel Eshleman, and Jared S. Soileau. 2017. Business strategy and auditor reporting. Auditing: A Journal of Practice \& Theory 36: 63-86.

Citron, David B., and Richard J. Taffler. 2001. Ethical behaviour in the UK audit profession: The case of the self-fulfilling prophecy under going-concern uncertainties. Journal of Business Ethics 29: 353-63. [CrossRef]

Cohen, Sandra, Antonella Costanzo, and Francesca Manes-Rossi. 2017. Auditors and early signals of financial distress in local governments. Managerial Auditing Journal 32: 234-50. [CrossRef]

Conefrey, Thomas, and John Fitz Gerald. 2010. Managing housing bubbles in regional economies under EMU: Ireland and Spain. National Institute Economic Review 211: 91-108. [CrossRef]

Cultrera, Loredana, and Xavier Brédart. 2016. Bankruptcy prediction: The case of Belgian SMEs. Review of Accounting and Finance 15: 1-23. [CrossRef]

Cunnigham, Lawrence A. 2006. Too big to fail: moral hazard in auditing and the need to restructure the industry before it unravels. Columbia Law Review 106: 1-68.

Daily, Catherine M. 1996. Governance patterns in bankruptcy reorganizations. Strategic Management Journal 17: 355-75. [CrossRef]

DeFond, Mark, and Jieying Zhang. 2014. A review of archival auditing research. Journal of Accounting and Economics 58: 275-326. [CrossRef]

DeFond, Mark L., Kannan Raghunandan, and K. R. Subramanyam. 2002. Do non-audit service fees impair auditor independence? Evidence from going concern audit opinions. Journal of Accounting Research 40: 1247-74. [CrossRef]

Desai, Vikram, Joung W. Kim, Rajendra P. Srivastava, and Renu V. Desai. 2017. A study of the relationship between a going concern opinion and its financial distress metrics. Journal of Emerging Technologies in Accounting 14: 17-28. [CrossRef]

Díaz-Martínez, Zuleyka, Alicia Sanchís-Arellano, and María Jesús Segovia-Vargas. 2009. Analysis of Financial Instability by Means of Decision Trees and Lists. In Emerging Topics in Macroeconomics. Edited by Richard O. Bailly. New York: Editorial Nova Publishers, pp. 303-27.

Dopuch, Nicholas, Robert W. Holthausen, and Richard W. Leftwich. 1987. Predicting audit qualifications with financial and market variables. The Accounting Review 62: 431-54.

Du Jardin, Philippe. 2015. Bankruptcy prediction using terminal failure processes. European Journal of Operational Research 242: 286-303. [CrossRef]

Eutsler, Jared, Erin Burrell Nickell, and Sean W. G. Robb. 2016. Fraud Risk Awareness and the Likelihood of Audit Enforcement Action. Accounting Horizons 30: 379-92. [CrossRef]

Feldmann, Dorothy A., and William J. Read. 2010. Auditor conservatism after Enron. Auditing: A Journal of Practice and Theory 29: 267-78. [CrossRef]

Frank, Eibe, and Ian H. Witten. 1998. Generating Accurate Rule Sets without Global Optimization. Working Paper. Hamilton: University of Waikato, Department of Computer Science.

Gaeremynck, Ann, Sofie Van Der Meulen, and Marleen Willekens. 2008. Audit-firm portfolio characteristics and client financial reporting quality. European Accounting Review 17: 243-70. [CrossRef]

García-Blandón, Josep, and Josep Maria Argiles-Bosch. 2013. Audit tenure and audit qualifications in a low litigation risk setting: An analysis of the Spanish market. Estudios de Economía 40: 133-56. [CrossRef] 
Geiger, Marshall A., and Kanan Raghunandan. 2001. Bankruptcies, audit reports, and the reform act. Auditing: A Journal of Practice and Theory 20: 187-95. [CrossRef]

Geiger, Marshall A., and Kanan Raghunandan. 2002. Auditor tenure and audit reporting failures. Auditing: A Journal of Practice and Theory 21: 67-78. [CrossRef]

Geiger, Marshall A., Kanan Raghunandan, and Dasaratha V. Rama. 2005. Recent changes in the association between bankruptcies and prior audit opinions. Auditing: A Journal of Practice and Theory 24: 21-35. [CrossRef]

Geiger, Marshall A., Kanan Raghunandan, and William Riccardi. 2014. The Global Financial Crisis: US bankruptcies and going-concern audit opinions. Accounting Horizons 28: 59-75. [CrossRef]

Hope, Ole-Kristian, Danqi Hu, and Wuyang Zhao. 2017. Third-party consequences of short-selling threats: The case of auditor behavior. Journal of Accounting and Economics 63: 479-98. [CrossRef]

Hopwood, William, James McKeown, and Jane Mutchler. 1989. A test of the incremental explanatory power of opinions qualified for consistency and uncertainty. The Accounting Review 64: 28-48.

Ittonen, Kim, Per C. Tronnes, and Leon Wong. 2017. Substantial doubt and the entropy of auditors' going concern modifications. Journal of Contemporary Accounting E Economics 13: 134-47.

Joe, Jennifer R. 2003. Why press coverage of a client influences the audit opinion. Journal of Accounting Research 41: 109-33. [CrossRef]

Kausar, Asad, and Clive S. Lennox. 2017. Balance sheet conservatism and audit reporting conservatism. Journal of Business Finance \& Accounting 44: 897-924.

Kausar, Asad, Richard J. Taffler, and Christine E. L. Tan. 2017. Legal regimes and investor response to the auditor's going-concern opinion. Journal of Accounting, Auditing E Finance 32: 40-72.

Khurana, Inder K., and Kris K. Raman. 2006. Do investors care about the auditor's economic dependence on the client? Contemporary Accounting Research 23: 977-1016. [CrossRef]

Kida, Thomas. 1980. An investigation into auditors' continuity and related qualification judgments. Journal of Accounting Research 18: 506-23. [CrossRef]

Kim, Minchoul, Minho Kim, and Ronald D. McNiel. 2008. Predicting survival prospect of corporate restructuring in Korea. Applied Economics Letters 15: 1187-90. [CrossRef]

Kirkos, Efstathios. 2015. Assessing methodologies for intelligent bankruptcy prediction. Artificial Intelligence Review 43: 83-123. [CrossRef]

Knechel, W. Robert, and Ann Vanstraelen. 2007. The relationship between auditor tenure and audit quality implied by going concern opinions. Auditing: A Journal of Practice and Theory 26: 113-31. [CrossRef]

Koh, Wei-Chem, and Kin-Wai Lee. 2017. Do Auditors Recognize Managerial Risk-Taking Incentives? International Journal of Business 22: 206-29.

Koyuncugil, Ali Serhan, and Nermin Ozgulbas. 2012. Financial early warning system model and data mining application for risk detection. Expert Systems with Applications 39: 6238-53. [CrossRef]

Krishnan, Jagan, and Jayanthi Krishnan. 1997. Litigation risk and auditor resignations. The Accounting Review 72: 539-60.

Kuhn, John R., James F. Courtney, and Bonnie Morris. 2015. A theory of complex adaptive inquiring organizations: Application to continuous assurance of corporate financial information. The Knowledge Engineering Review 30: 265-96. [CrossRef]

Kumar, Krishna, and Lucy Lim. 2015. Was Andersen's audit quality lower than its peers? A comparative analysis of audit quality. Managerial Auditing Journal 30: 911-62. [CrossRef]

Kumar, P. Ravi, and Vadlamani Ravi. 2007. Bankruptcy prediction in banks and firms via statistical and intelligent techniques: A review. European Journal of Operational Research 180: 1-28. [CrossRef]

Laitinen, Erkki K., and Teija Laitinen. 2009. Effect of accruals on financial, non-financial, and audit information in payment default prediction. International Journal of Accounting, Auditing and Performance Evaluation 5: 353-83. [CrossRef]

Lenard, Mary Jane, Pervaiz Alam, and Gregory R. Madey. 1995. The application of neural networks and a qualitative response model to the auditor's going concern uncertainty decision. Decision Sciences 26: 209-27. [CrossRef]

Lennox, Clive S. 1999. The accuracy and incremental information content of audit reports in predicting bankruptcy. Journal of Business Finance and Accounting 26: 757-78. [CrossRef]

Lennox, Clive S., and Asad Kausar. 2017. Estimation risk and auditor conservatism. Review of Accounting Studies 22: 185-216. [CrossRef] 
Lim, Chee-Yeow, and Hun-Tong Tan. 2010. Does auditor tenure improve audit quality? Moderating effects of industry specialization and fee dependence. Contemporary Accounting Research 27: 923-57. [CrossRef]

Louwers, Timothy J. 1998. The relation between going-concern opinions and the auditor's loss function. Journal of Accounting Research 36: 143-55. [CrossRef]

Louwers, Timothy J., Frank M. Messina, and Michael D. Richard. 1999. The auditor's going-concern disclosure as a self-fulfilling prophecy: A discrete-time survival analysis. Decision Sciences 30: 805-24. [CrossRef]

Lowe, D. Jordan, and Philip M. J. Reckers. 1994. The effects of hindsight bias on jurors' evaluations of auditor decisions. Decision Sciences 25: 401-26. [CrossRef]

Lundberg, C. Gustav, and Brian M. Nagle. 2002. Post-decision inference editing of supportive and counter indicative signals among external auditors in a going concern judgment. European Journal of Operational Research 136: 264-81. [CrossRef]

McKee, Thomas E. 1995. Predicting bankruptcy via induction. Journal of Information Technology 10: 26-36. [CrossRef]

McKee, Thomas E. 2003. Rough sets bankruptcy prediction models versus auditor signalling rates. Journal of Forecasting 22: 569-86. [CrossRef]

McKeown, James C., Jane F. Mutchler, and William Hopwood. 1991. Towards an explanation of auditor failure to modify the audit opinions of bankrupt companies. Auditing: A Journal of Practice and Theory 10: 1-13.

McNichols, Maureen F. 2002. Discussion of the quality of accruals and earnings: The role of accrual estimation errors. The Accounting Review 77: 61-69. [CrossRef]

Menon, Krishnagopal, and David D. Williams. 1994. The insurance hypothesis and market prices. The Accounting Review 69: 327-42.

Min, Jae H., and Young-Chan Lee. 2005. Bankruptcy prediction using support vector machine with optimal choice of kernel function parameters. Expert Systems with Applications 28: 603-14. [CrossRef]

Min, Sung-Hwan, Jumin Lee, and Ingoo Han. 2006. Hybrid genetic algorithms and support vector machines for bankruptcy prediction. Expert Systems with Applications 31: 652-60. [CrossRef]

Muñoz-Izquierdo, Nora, María-del-Mar Camacho-Miñano, and David Pascual-Ezama. 2017. The content of the audit report in the year prior to bankruptcy filing. Empirical evidence from Spain. Spanish Journal of Finance and Accounting 46: 92-126.

Muñoz-Izquierdo, Nora, María Jesús Segovia-Vargas, María-del-Mar Camacho-Miñano, and David Pascual-Ezama. 2019. Explaining the causes of business failure using audit report disclosures. Journal of Business Research 98: 403-14. [CrossRef]

Myers, Linda A., Jonathan E. Shipman, Quinn T. Swanquist, and Robert L. Whited. 2018. Measuring the market response to going concern modifications: The importance of disclosure timing. Review of Accounting Studies 23: 1512-42. [CrossRef]

Ogneva, Maria K., Raghunandan Subramanyam, and Kannan Raghunandan. 2007. Internal control weakness and cost of equity: Evidence from SOX Section 404 disclosures. The Accounting Review 82: 1255-97. [CrossRef]

Pedrosa Rodríguez, M. Áurea, and Francisco López-Corrales. 2018. Autors' response to the global financial crisis: Evidence from Spanish non-listed companies. Spanish Journal of Finance and Accounting 47: 400-31.

Piñeiro-Sánchez, Carlos, Pablo de Llano-Monelos, and Manuel Rodríguez-López. 2012. Evaluation of the likelihood of financial failure. Empirical contrast of the informational content audit of accounts. Spanish Journal of Finance and Accounting 46: 565-87.

Piñeiro-Sánchez, Carlos, Pablo de Llano-Monelos, and Manuel Rodríguez-López. 2013. A parsimonious model to forecast financial distress, based on audit evidence. Contaduría y Administración 58: 151-73. [CrossRef]

Pratt, Jamie, and James D. Stice. 1994. The effects of client characteristics on auditor litigation risk judgments, required audit evidence, and recommended audit fees. The Accounting Review 69: 639-56.

Raghunandan, Kannan, and Dasaratha V. Rama. 1995. Audit reports for companies in financial distress: Before and after SAS No. 59. Auditing: A Journal of Practice and Theory 14: 50-63.

Ragothaman, Srinivasan, Jon Carpenter, and Thomas Buttars. 1995. Using rule induction for knowledge acquisition: An expert systems approach to evaluating material errors and irregularities. Expert Systems with Applications 9: 483-90. [CrossRef]

Read, William J., and Ari Yezegel. 2016. Auditor tenure and going concern opinions for bankrupt clients: Additional evidence. Auditing: A Journal of Practice and Theory 35: 163-79. [CrossRef] 
Read, William J., and Ari Yezegel. 2018. Going-concern opinion decisions on bankrupt clients: Evidence of long-lasting auditor conservatism? Advances in Accounting 40: 20-26. [CrossRef]

Robinson, Dahlia. 2008. Auditor independence and auditor-provided tax service: Evidence from going-concern audit opinions prior to bankruptcy filings. Auditing: A Journal of Practice and Theory 27: 31-54. [CrossRef]

Rodríguez-López, Manuel, Carlos Piñeiro-Sánchez, and Pablo de Llano-Monelos. 2014. Financial risk determination of failure by using parametric model, artificial intelligence and audit information. Estudios de Economía 41: 187-217.

Ruiz-Barbadillo, Emiliano, Nieves Gómez-Aguilar, Cristina De Fuentes-Barberá, and María Antonia García-Benau. 2004. Audit quality and the going-concern decision-making process: Spanish evidence. European Accounting Review 13: 597-620. [CrossRef]

Schwartz, Kenneth B., and Krishnagopal Menon. 1985. Auditor switches by failing firms. The Accounting Review 60: 248-61.

Shu, Pei-Gi, Tsung-Kang Chen, and Wen-Jye Hung. 2015. Audit duration quality and client credit risk. Asia-Pacific Journal of Accounting and Economics 22: 137-62. [CrossRef]

Sikka, Prem. 2009. Financial crisis and the silence of the auditors. Accounting, Organizations and Society 34: 868-73. [CrossRef]

Stanisic, Milovan, Danka Stefanovic, Nada Arezina, and Vule Mizdrakovic. 2013. Analysis of auditors' reports and bankruptcy risk in banking sector in the Republic of Serbia. The Amfiteatru Economic Journal 15: 431-41.

Stanley, Jonathan D. 2011. Is the audit fee disclosure a leading indicator of clients' business risk? Auditing: A Journal of Practice and Theory 30: 157-79. [CrossRef]

Sun, Jie, Hui Li, Qing-Hua Huang, and Kai-Yu He. 2014. Predicting financial distress and corporate failure: A review from the state-of-the-art definitions, modelling, sampling, and featuring approaches. Knowledge-Based Systems 57: 41-56. [CrossRef]

Tascón-Fernández, María T., and Francisco J. Castaño-Gutiérrez. 2012. Variables and models for the identification and prediction of business failure: Revision of recent empirical research advances. Spanish Accounting Review 15: 7-58.

Van Caneghem, Tom, and Geert Van Campenhout. 2012. Quantity and quality of information and SME financial structure. Small Business Economics 39: 341-58. [CrossRef]

Van Peursem, Karen, and Yi Chiann Chan. 2014. Forecasting New Zealand corporate failures 2001-10: Opportunity lost? Australian Accounting Review 24: 276-88. [CrossRef]

Vanstraelen, Ann. 2000. Impact of renewable long-term audit mandates on audit quality. European Accounting Review 9: 419-42. [CrossRef]

Vanstraelen, Ann. 2002. Auditor economic incentives and going-concern opinions in a limited litigious continental European business environment: Empirical evidence from Belgium. Accounting and Business Research 32: 171-86. [CrossRef]

Wu, Wei-Wen. 2010. Beyond business failure prediction. Expert Systems with Applications 37: 2371-76. [CrossRef]

Yeh, Ching-Chiang, Der-Jang Chi, and Yi-Rong Lin. 2014. Going-concern prediction using hybrid random forests and rough set approach. Information Sciences 254: 98-110. [CrossRef]

Zdolsek, D., and T. Jagric. 2011. Audit opinion identification using accounting ratios: Experience of United Kingdom and Ireland. Actual Problems of Economics 115: 285-310.

Zięba, Maciej, Sebastian K. Tomczak, and Jakub M. Tomczak. 2016. Ensemble boosted trees with synthetic features generation in application to bankruptcy prediction. Expert Systems with Applications 58: 93-101. [CrossRef]

(C) 2019 by the authors. Licensee MDPI, Basel, Switzerland. This article is an open access article distributed under the terms and conditions of the Creative Commons Attribution (CC BY) license (http://creativecommons.org/licenses/by/4.0/). 